\title{
PATOGENISITAS EMPAT ISOLAT JAMUR Beauveria bassiana (Bals.) Vuill. TERHADAP ULAT API (Setothosea spp.) DI LABORATORIUM
}

\author{
Windari Anggraini, Yuyun Fitriana, Agus M. Hariri \& Purnomo \\ Jurusan Agroteknologi, Fakultas Pertanian, Universitas Lampung \\ J1. Prof. Soemantri Brojonegoro, No. 1 Bandar Lampung 35145 \\ Email: windarianggraini42@gmail.com
}

\begin{abstract}
ABSTRAK
Penelitian ini bertujuan untuk mengetahui karakter empat isolat jamur B.bassiana (Bbyf 22, Bbyf 24, Bbyf, dan BbTa) dalam pertambahan diameter koloni, kerapatan spora, dan perkecambahan sporasertakemampuan tiga isolat jamur $B$. bassiana dalam menimbulkan mortalitas terhadap ulat api (Setothosea spp.).Penelitian inidilaksanakan di Laboratorium Bioteknologi Pertanian, Fakultas Pertanian, Universitas Lampung, dari bulan Juli 2016 sampai Januari 2017. Penelitian ini terdiri dari dua set percobaan, yaitu percobaan pertama untuk mengetahui pertambahan diameter koloni, kerapatan spora, dan perkecambahan sporasecara in vitrodengan Rancangan Acak Lengkap (RAL) dan diulang lima kali. Percoban kedua uji patogenisitas jamur $B$. bassiana terhadap ulat api (Setothosea spp.) dengan Rancangan Acak Lengkap (RAL) dan diulang tiga kali dengan konsentrasi $10^{6}, 10^{7}$, dan $10^{8}$. Pengamatan dilakukan terhadap diameter koloni, kerapatan spora, perkecambahan spora, dan mortalitas. Data diuji dengan analisis ragam dan nilai tengah perlakuan diuji dengan uji Duncan Multiple Range Test (DMRT) pada taraf $5 \%$.Keempat isolat jamurB. bassiana memiliki pertambahan koloni, kerapatan spora dan daya berkecambah (viabilitas) yang berbeda-beda, dari keempat jamur tersebut isolat Bbyf 24 yang memiliki pertambahan koloni, kerapatan spora dan daya berkecambah (viabilitas) yang paling baik dibandingkan $B$. bassiana asal Tanggamus. Tiga isolat $B$. bassiana dari tiga tingkat pengenceran mampu menimbulkan mortalitas pada ulat api, namun isolat yang mampu menimbulkan mortalitas ulat api dengan baik yaitu isolat Bbyf danBbyf24 mencapai 33\% dengan tingkat pengenceran $10^{8}$.
\end{abstract}

Kata kunci: Beauveria bassiana, Setothosea spp., kerapatan spora, viabilitas, mortalitas

\section{PENDAHULUAN}

Kelapa sawit (Elaeis guineensis Jacq.) merupakan salah satu tanaman perkebunan yang menduduki posisi penting di Indonesia. Hal ini dikarenakan kelapa sawit mampu menciptakan kesempatan kerja yang mengarah pada kesejahteraan masyarakat serta memegang peranan penting dan menjadi devisa terbesar bagi Negara dari sektor non migas selain karet dan kopi (Sastrosayono, 2003).

Direktorat Jenderal Perkebunan (2015) menjelaskan bahwa pada statistik perkebunan tahun 2015-2017 produksikelapa sawit di Indonesia setiap tahunnya meningkat. Pada tahun 2015 mencapai produksi kelapa sawit mencapai 26.051 .518 ton, tahun 2016 memperoleh hasil produksi sebesar 33.229.381 ton, dan tahun 2017 produksi kelapa sawit mencapai 35.359.384 ton.

Permasalahan utama dalam budidaya tanaman kelapa sawit adalah organisme pengganggu tanaman, salah satunya ulat pemakan daun yaitu ulat api (Setothosea asigna). Ulat api memakan daun hingga berlubang atau habis sama sekali hingga menyisakan tulang daun. Dalam kondisi yang parah tanaman akan kehilangan daun sekitar 90\% (Satriawan, 2011). Prawirosukarto (2002) mengatakan bahwa kerusakan daun yang terjadi pada tanaman kelapa sawit berumur 8 tahun, diperkirakan penurunan produksi mencapai 30$40 \%$ pada 2 tahun setelah terjadi kehilangan daun akibat serangan ulat pemakan daun kelapa sawit (UPDKS). Kerusakan daun yang terjadi pada tanaman kelapa sawit yang lebih muda, dapat menyebabkan kehilangan hasil yang kecil. Kehilangan daun sebesar $50 \%$ pada tanaman kelapa sawit yang berumur 1-2 tahun, masing-masing akan mengakibatkan penurunan produksi sebesar 12$24 \%$ dan $<4 \%$ pada dua tahun pasca serangan.

Ulat api merupakan salah satu hama pemakan daun pada tanaman kelapa sawit. Menurut Prawirosukarto dkk. (2003), ambang ekonomi kedua ulat api (Setothosea asigna dan Setora nitens) pada tanaman kelapa sawit rata-rata 5-10 ekor perpelepah untuk tanaman yang berumur 7 tahun ke atas dan 5 ekor larva untuk tanaman yang lebih muda.

Pengendalian ulat api dapat dilakukan dengan cara mekanis, biologi maupun kimia tergantung pada intensitas serangannya. Untuk intensitas ringan, 
serangan ulat api dapat diatasi dengan mengambil ulat api yang ada pada tanaman kelapa sawit yang terserang secara manual (hand picking). Untuk pengendalian secara hayati dapat dilakukan dengan menggunakan musuh alami seperti predator, patogen hama/ entomopatogen atau parasitoid (Prawirosukarto dkk., 1997).

Beberapa agensia hayati telah banyak digunakan untuk mengendalikan ulat api, antara lain Bacillus thuringiensis, Cordyceps militaris dan Multi-Nucleo Polyhydro Virus (MNPV), dan Beauveria bassiana.Beauveria bassiana (Bals.) Vuill. adalah salah satu jamur entomopatogenik yang berpotensi untuk dikembangkan sebagaiagensia pengendali hayati. Beauveria bassiana telah dilaporkan efektif dalam menekan perkembangan larva Lepidoptera antara lain ulat api Darna catenata (Saranga \& Daud, 1993), ulat jengkal Ectropis bhurmitra (Widayat \& Rayati, 1993), ulat polong Helicoverpa armigera (Suharto dkk., 1998; Soetopo, 2004), ulat kantung Metisa plana (Badan Penelitian dan Pengembangan Pertanian, 2013), ulat grayak Spodoptera litura (Arsyiogi, 2014). Selain itu, B. bassiana juga efektif untuk mengendalikan Aphis craccivora (Purnama dkk., 2003), Cylas formicarius (Noya, 2009), Helopeltis spp. (Pratiwi, 2016), dan Thrips tabaci (Fitriana dkk., 2015). Tarigan dkk. (2013) melaporkan jamur B. bassiana mampu menekan intensitas serangan ulat api di laboratorium sebesar $4,17 \%$. B. bassiana juga dimanfaatkan untuk mengendalikan serangan ulat pemakan tajuk tanaman kelapa sawit, Darna catenatadi Sulawesi Selatan dengan mortalitas ulat rata-rata 46-93\% (Saranga \& Daud, 1993).

Penelitian ini bertujuan untuk mengetahui kemampuan empat isolat jamur B. bassiana (Bbyf 22, Bbyf 24, Bbyf, dan BbTa) dalam pertambahan diameter koloni, kerapatan spora, dan perkecambahan spora dan mengetahui kemampuan tiga isolat jamur $B$. bassiana
(Bbyf, Bbyf 24, dan BbTa) dalam menimbulkan mortalitas terhadap ulat api (Setothosea spp.).

\section{BAHAN DAN METODE}

Penelitian ini dilaksanakan di Laboratorium Bioteknologi Pertanian, Fakultas Pertanian, Universitas Lampung, dari bulan Juli 2016 sampai Januari 2017. Penelitian ini terdiri dari dua set percobaan, yaitu percobaan pertama untuk mengetahui pertambahan diameter koloni, kerapatan spora, dan perkecambahan sporasecara in vitro menggunakan empat isolat jamur B. bassiana (Bbyf 22, Bbyf 24, Bbyf, dan BbTa) yang diulang sebanyak 5 kalidengan Rancangan Acak Lengkap (RAL) dan diulang lima kali. Percoban kedua uji patogenisitas jamur $B$. bassiana terhadap ulat api (Setothosea spp.) menggunakan 9 perlakuan yang diulang sebanyak 3 kali dengan konsentrasi $10^{6}, 10^{7}$, dan $10^{8}$. Dalam 1 ulangan menggunakan 10 ekor serangga dengan Rancangan Acak Lengkap (RAL). Pengamatan dilakukan terhadap diameter koloni, kerapatan spora, perkecambahan spora, dan mortalitas. Data diuji dengan analisis ragam dan nilai tengah perlakuan diuji dengan uji Duncan Multiple Range Test (DMRT) pada taraf $5 \%$.

\section{HASIL DAN PEMBAHASAN}

Hasil analisis pertambahan diameter koloni $B$. bassiana mulai dari 3 hingga 15 hari setelah inokulasi (hsi) dapat dilihat pada Tabel 1. Tabel 1 menunjukkan bahwa pada 3 hsi, diameter koloni B. bassianaisolat Bbyf secara statistika tidak berbeda nyata dengan Bbyf 24. Isolat Bbyf 22 memiliki nilai diameter terkecil dibanding BbTa. Hasil analisis ragam diameter koloni keempat isolat $B$. bassiana pada 7 hsi tidak nyata. Sedangkan pada $11 \mathrm{hsi}$, isolat Bbyf 24 memiliki diameter koloni sebesar 4,39 cm namun tidak beda nyata dengan

Tabel 1. Diameter koloni empat isolat B. bassiana pada media PSA

\begin{tabular}{lcccc}
\hline \multirow{2}{*}{ Isolat B. bassiana } & \multicolumn{4}{c}{ Diameter koloni B.bassiana $(\mathrm{cm})$} \\
\cline { 2 - 5 } & 3 & 7 & 11 & 15 \\
\hline Bbyf & $1,38 \mathrm{c}$ & 2,60 & $4,15 \mathrm{~b}$ & $5,33 \mathrm{~b}$ \\
Bbyf 22 & $1,18 \mathrm{a}$ & 2,65 & $4,29 \mathrm{c}$ & $5,32 \mathrm{~b}$ \\
Bbyf 24 & $1,34 \mathrm{bc}$ & 2,53 & $4,39 \mathrm{c}$ & $5,51 \mathrm{~b}$ \\
BbTa & $1,28 \mathrm{~b}$ & 2,38 & $3,36 \mathrm{a}$ & $4,54 \mathrm{a}$ \\
\hline F hitung & $14,76^{*}$ & $3,24^{\text {th }}$ & $217,05^{*}$ & $19,67^{*}$ \\
\hline
\end{tabular}

Keterangan $: *=$ nyata, $\mathrm{tn}=$ tidak berbeda nyata pada taraf $5 \%$ 
isolat Bbyf 22, dan beda nyata dengan isolat Bbyf dan BbTa. Pada hari terakhir pengamatan (15 hsi), isolat Bbyf tidak beda nyata dengan Bbyf 22 dan Bbyf 24 dan beda nyata lebih kecil dengan $\mathrm{BbTa}$. Isolat $\mathrm{BbTa}$ mempunyai diameter terkecil dari 7-15 hsi. Hasil pengamatan kerapatan spora $B$. bassiana dapat dilihat pada Tabel 2. Secara statistika, kerapatan spora isolat Bbyf 24 berbeda nyata lebih besar dibanding 3 isolat $B$. bassiana lainnya yaitu $20,80 \times 10^{8} \mathrm{spora} / \mathrm{ml}$. Sedangkan 3 isolat Bbyf, Bbyf 22, dan BbTa secara statistika mempunyai kerapatan spora yang sama yaitu masingmasing $8,20 \times 10^{8} ; 7,00 \times 10^{8}$ dan $7,90 \times 10^{8}$ spora $/ \mathrm{ml}$.
Hasil analisis statistika perkecambahan spora jamur $B$. bassiana dapat dilihat pada Tabel 3. Spora $B$. bassiana yang memiliki daya berkecambah paling baik yaitu isolat Bbyf 24 mencapai $75,40 \%$ dan berbeda nyata dengan isolat Bbyf, Bbyf 22, dan BbTa. Sedangkan 3 isolat Bbyf, Bbyf 22, dan BbTa secara statistika sama yaitu masing-masing sebesar $71,2 \% ; 71,4 \%$ dan $69,0 \%$.

Mortalitas ulat api (Setothosea spp.) pada 7 hsa yang diaplikasi dengan 3 isolat $B$. bassiana dengan tingkat pengenceran $10^{6}, 10^{7}$, dan $10^{8}$ dapat dilihat pada Tabel 4. Hasil analisis ragam menunjukkan bahwa mortalitas ulat api pada 7 hsa dengan 3 tingkat

Tabel 2. Kerapatan spora empat isolat B. bassiana pada media PSA

\begin{tabular}{|c|c|}
\hline Isolat $B$. bassiana & Kerapatan spora $\left(\times 10^{8} / \mathrm{ml}\right)$ \\
\hline Bbyf & $8,20 \mathrm{a}$ \\
\hline Bbyf 22 & $7,00 \mathrm{a}$ \\
\hline Bbyf 24 & $20,80 \mathrm{~b}$ \\
\hline $\mathrm{BbTa}$ & $7,90 \mathrm{a}$ \\
\hline F hitung & $473,01^{*}$ \\
\hline
\end{tabular}

Keterangan: huruf yang tidak sama menunjukkan berbeda nyata menurut uji DMRT pada taraf 5\%

Tabel 3. Daya berkecambah spora B. bassiana yang telah diinkubasi selama 16 jam pada media PSA Isolat B. bassiana Spora B. bassiana berkecambah (\%)

\begin{tabular}{lc}
\hline Bbyf & $71,20 \mathrm{a}$ \\
Bbyf 22 & $71,40 \mathrm{a}$ \\
Bbyf 24 & $75,40 \mathrm{~b}$ \\
BbTa & $69,00 \mathrm{a}$ \\
\hline F hitung & $3,91^{*}$ \\
\hline
\end{tabular}

Keterangan: huruf yang tidak sama menunjukkan berbeda nyata menurut uji DMRT pada taraf $5 \%$

Tabel 4. Mortalitas ulat api (Setothosea spp.) dengan tingkat pengenceran $10^{6}, 10^{7}$ dan $10^{8}$ spora jamur Beauveria bassianapada 7 hsa

\begin{tabular}{lccc}
\hline \multirow{2}{*}{ Perlakuan } & \multicolumn{3}{c}{ Mortalitas Ulat Api (Setothosea spp.) (\%) } \\
& $10^{6}$ & $10^{7}$ & $10^{8}$ \\
\hline Kontrol & 0,00 & 0,00 & 0,00 \\
Bbyf & 26,67 & 30,00 & 33,33 \\
Bbyf 24 & 26,67 & 33,33 & 33,33 \\
BbTa & 23,33 & 26,67 & 30,00 \\
\hline F hitung & $2,21^{\text {tn }}$ & $2,61^{\text {tn }}$ & $2,70^{\text {tn }}$ \\
\hline
\end{tabular}

Keterangan: $*$ nyata, $\mathrm{tn}=$ tidak berbeda nyata pada taraf $5 \%$ 
konsentrasi tidak berbeda nyata pada taraf $5 \%$. Hasil penelitian mortalitas ulat api dapat dilihat pada Gambar 1. Gambar 1 menunjukkan bahwa tingkat pengenceran yang efektif dalam menginfeksi ulat api adalah tingkat pengenceran $10^{8}$. Pada tingkat pengenceran $10^{8}$ masingmasing jamur mampu menginfeksi ulat api sebesar 33\% (Bbyf), 33\% (Bbyf 24), dan 30\% (BbTa).

Hasil penelitian menunjukkan bahwa isolat Bbyf 24 lebih tinggi dibandingkan isolat Bbyf dan Bbyf 22, maupun pada isolat $\mathrm{BbTa}$. Hal ini dapat terlihat dari kemampuan isolat Bbyf 24 dalam pertambahan koloni, kerapatan spora, daya berkecambah (viabilitas) serta kemampuannya dalam menginfeksi ulat api.Isolat Bbyf 24 memiliki jumlah spora berkecambah lebih banyak

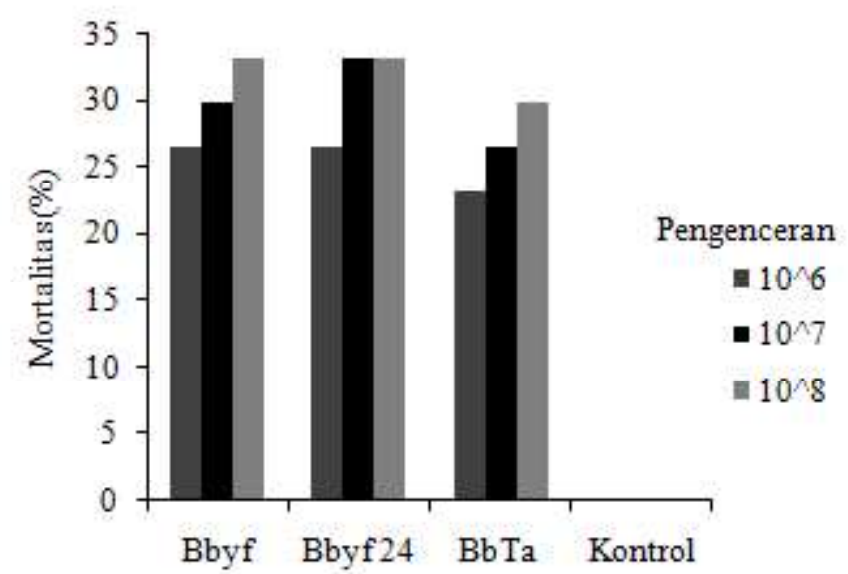

Gambar 1. Mortalitas ulat api menggunakan 3 isolat pada tingkat pengenceran $10^{6}, 10^{7}$, dan $10^{8}$

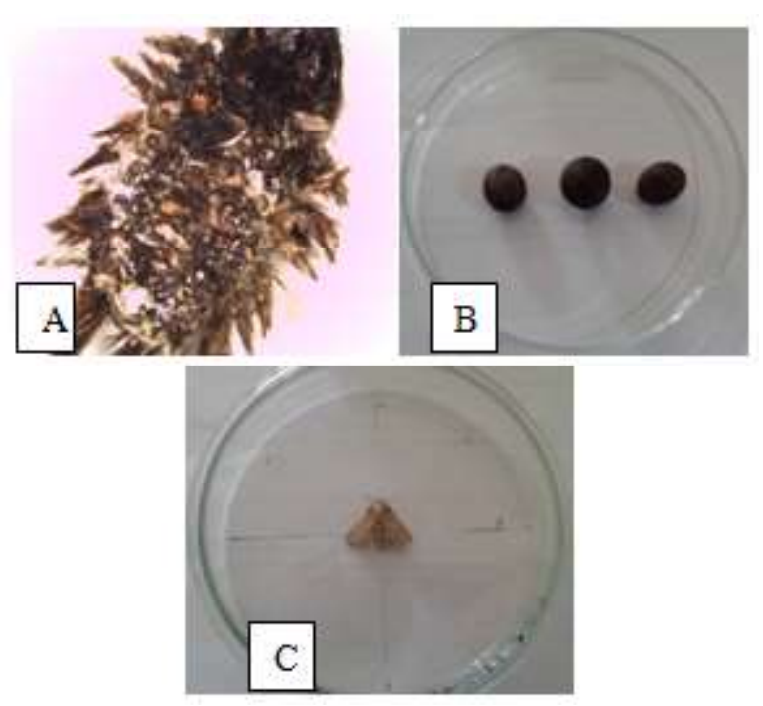

Gambar 2. Mortalitas ulat api. A.Tubuh ulat api (Setothosea spp.) yang terinfeksi jamur B.bassiana (Bbyf 24) dengan perbesaran 400x; B. Pupa ulat api (Setothosea spp.); C. Ngengat ulat api (Setothosea spp.) dibandingkan dengan isolat lainnya sehingga untuk menginfeksi ulat api memiliki peluang yang lebih besar.

Berdasarkan grafik mortalitas (Gambar 1), kerapatan spora $10^{8} / \mathrm{ml}$ mampu menyebabkan persentase mortalitas yang palingbesar. Semakin tinggi kerapatan spora, maka semakin tinggi peluang ulat api terinfeksi. Noya (2009) melaporkan bahwa jamur $B$. bassiana pada kerapatan spora $10^{8} / \mathrm{ml}$ mampu menyebabkan mortalitas imago Cylas formicarius lebih dari $50 \%$. Penggunaan kerapatan spora $10^{8} / \mathrm{ml}$ pada penelitian Rosfiansyah (2009) mampu menekan luas serangan hingga $25,40 \%$ dan intensitas serangan hingga $13,79 \%$.

Tingkat kerapatan spora yang diaplikasikan untuk mengendalikan serangga juga berpengaruh untuk menunjukkan tingkat kematian yang berbeda. Tingkat kerapatan jamur B. bassiana yang diaplikasikan pada larva Spodoptera litura instar 3 yaitu $10^{5}, 10^{6}, 10^{7} \mathrm{dan}$ $10^{8} \mathrm{spora} / \mathrm{ml}$ menunjukkan bahwa kerapatan $10^{8} \mathrm{spora} /$ $\mathrm{ml}$ mortalitasnya lebih tinggi dibandingkan kerapatan $10^{5}$, $10^{6}, 10^{7} \mathrm{spora} / \mathrm{ml}$. Persentase kematian pada kerapatan $10^{8} \mathrm{spora} / \mathrm{ml}$ adalah $75 \%$, sedangkan pada kerapatan $10^{5}$, $10^{6}, 10^{7} \mathrm{spora} / \mathrm{ml}$ adalah $40 \%, 48 \%$ dan $60 \%$ (Arsyiogi, 2014). Hasil penelitian Bell dan Hamale (1970) menyebutkan bahwa dengan menggunakan konsentrasi spora $1,8 \times 10^{9} / \mathrm{ml}$ mampu membunuh $100 \%$ larva Chalcodermus aeneus dalam waktu 6-7 hari.

Pada pengamatan mortalitas ulat api secara visual, kriteria yang terlihat bahwa ulat api sudah terinfeksi jamur $B$. bassiana adalah penurunan nafsu makan, adanya miselia jamur berwarna putih pada permukaan tubuh ulat api. Gejala awal, kondisi ulat api masih lunak, kemudian ulat api menjadi kaku dan mumifikasi saat jamur berkembang di dalam tubuh ulat api.

Hasil pengamatan (Gambar 2A) menunjukkan bahwa ulat api yang terinfeksi jamur B. bassiana tampak mengalami mumifikasi oleh miselia B. bassiana, namun tidak tampak menyeluruh permukaan tubuh ulat api. Ada beberapa ulat api yang tidak mengalami kematian menjadi pupa dan ngengat.

\section{KESIMPULAN}

Dari hasil penelitian dapat diambil kesimpulan bahwa keempat isolat jamur $B$. bassiana memiliki pertambahan koloni, kerapatan spora dan daya berkecambah (viabilitas) yang berbeda-beda, dari keempat jamur tersebut isolat Bbyf 24 yang memiliki pertambahan koloni, kerapatan spora dan daya berkecambah (viabilitas) yang paling baik dibandingkan $B$. bassiana asal Tanggamus. Tiga isolat $B$. bassianadari tiga tingkat pengenceran mampu 
menimbulkan mortalitas pada ulat api, namun isolat yang mampu menimbulkan mortalitas ulat api dengan baik yaitu isolat Bbyf dan Bbyf 24 mencapai 33\% dengan tingkat pengenceran $10^{8}$.

\section{DAFTAR PUSTAKA}

Arsyiogi, B. 2014. Mortalitas Aphis craccivora Koch. pada Beberapa Konsentrasi Beauveria bassiana Balsamo pada Tanaman Kacang Panjang. Skripsi. Universitas Bengkulu. Bengkulu. $2 \mathrm{hlm}$.

Badan Penelitian dan Pengembangan Pertanian. 2013. Ulat Kantung (Lepidoptera : Psychidae) sebagai Hama Potensial Jambu Mete dan Upaya Pengendaliannya. Warta Penelitian dan Pengembangan Perkebunan. Vol.19(2):1-4.

Bell, V.J. dan R. Hamale. 1970. Three Fungi Tested for Curculio, Chalodermus aeneus. Journal of Invert. Pathol. (15): 447-450.

Direktorat Jenderal Perkebunan. 2015. Statistik Perkebunan Indonesia. Jakarta.

Fitriana,Y., S. Shinobu, S. Katsuya, N. Issay, dan S. Tsutomu. 2015. Benomyl-resistant Beauveria bassiana (Hypocreales: Clavicipitaceae) mutants induced by ion beamsApplied Entomology and Zoology. Vol.50: 123-129.

Noya, S.H. 2009. Pathogenicity of Beauveria bassiana Isolates (Bals) Vuill on Cylas formicariusF. (Coleoptera: Curculionidae). J. Budidaya Pertanian. Vol.5: 81-83.

Pratiwi, D.2016. Patogenisitas Empat Isolat Cendawan Beauveria bassiana terhadap Hama Helopeltis spp. dan Riptortus linearis di Laboratorium. Skripsi. Universitas Lampung. Lampung.

Prawirosukarto, S. 2002. Pengenalan dan Pengendalian Hama Ulat pada Tanaman Kelapa Sawit. Pusat Penelitian Kelapa Sawit. Medan. $4 \mathrm{hlm}$.

Prawirosukarto, S., A. Djamin, dan Dj. Pardede. 1997. Pengendalian Oryctes rhinoceros dan Ulat Pemakan Daun Kelapa Sawit Secara Terpadu. Pusat Penelitian Kelapa Sawit. Medan.

Prawirosukarto, S., R.Y. Purba, C. Utomo, dan A. Susanto. 2003. Pengenalan dan Pengendalian Hama dan Penyakit Tanaman Kelapa Sawit. Medan.
Purnama, P.C., S.R. Nastiti dan J. Situmorang. 2003. Uji Patogenitas Jamur Beauveria bassiana (Bals.) Vuill. Isolat Magelang terhadap Aphis craccivora Koch. BioSmart. Vol.5(2): 81-88.

Rosfiansyah. 2009. Pengaruh Aplikasi Beauveria bassiana (Balsamo) Vuillemin dan Heterorhabditis sp. terhadap Serangan Hama Ubi jalar Cylas formicarius (Fabr.) (Coleoptera: Brentidae). Tesis. Sekolah Pasca-sarjana. Institut Pertanian Bogor. Bogor.

Saranga, A.P. dan I.D. Daud. 1993. Prospek Pemanfaatan Patogen Serangga untuk Pengendalian Serangga Hama di Sulawesi Selatan. Prosiding Simposium Patologi Serangga I. Yogyakarta. $9 \mathrm{hlm}$.

Sastrosayono, S. 2003. Budidaya Kelapa Sawit. Agromedia Pustaka. Jakarta.

Satriawan, R. 2011. Kelimpahan Populasi Ulat Api (Lepidoptera: Limacodidae) dan Ulat Kantung (Lepidoptera: Psychidae) serta Predator pada Perkebunan Kelapa Sawit (Elaeisguineensis Jacq.) Cikidang Plantation Estate, Sukabumi. Skripsi. Institut Pertanian Bogor. Bogor.

Soetopo, D. 2004. Efficacy of Selected Beauveria bassiana (Bals.) Vuill, Isolates in Combination with a Resistant Cotton Variety (PSB-Ct 9) againts the Cotton Bollworm, Helicoverpa armigera (Hubner) (Lepidoptera: Noctuidae). Disertasi. Philippines: University of The Philippines Los Banos.

Suharto, E.B., Trisusilowati, dan H. Purnomo. 1998. Kajian Aspek Fisiologik Beauveria bassiana dan Virulensinya terhadap Helicoverpa armigera. Jurnal Perlindungan Tanaman Indonesia. Vol.4(2): 112-119.

Tarigan, B., Syahrial, dan M.U. Tarigan. 2013. Uji Efektifitas Beauveria basianna dan Bacillus thuringiensis terhadap Ulat Api (Setothosea asigna Eeck, Lepidoptera, Limacodidae) di Laboratorium. Jurnal Agroteknologi. Vol.1(4): 139-146.

Widayat, W. dan D.J. Rayati. 1993. Pengaruh Frekuensi Penyemprotan Jamur Entomopatogenik terhadap Ulat Jengkal (Ectropis bhurmitra) di Perkebunan Teh. Prosiding Simposium Patologi Serangga I. Yogyakarta. $13 \mathrm{hlm}$. 